Provided for non-commercial research and education use. Not for reproduction, distribution or commercial use.

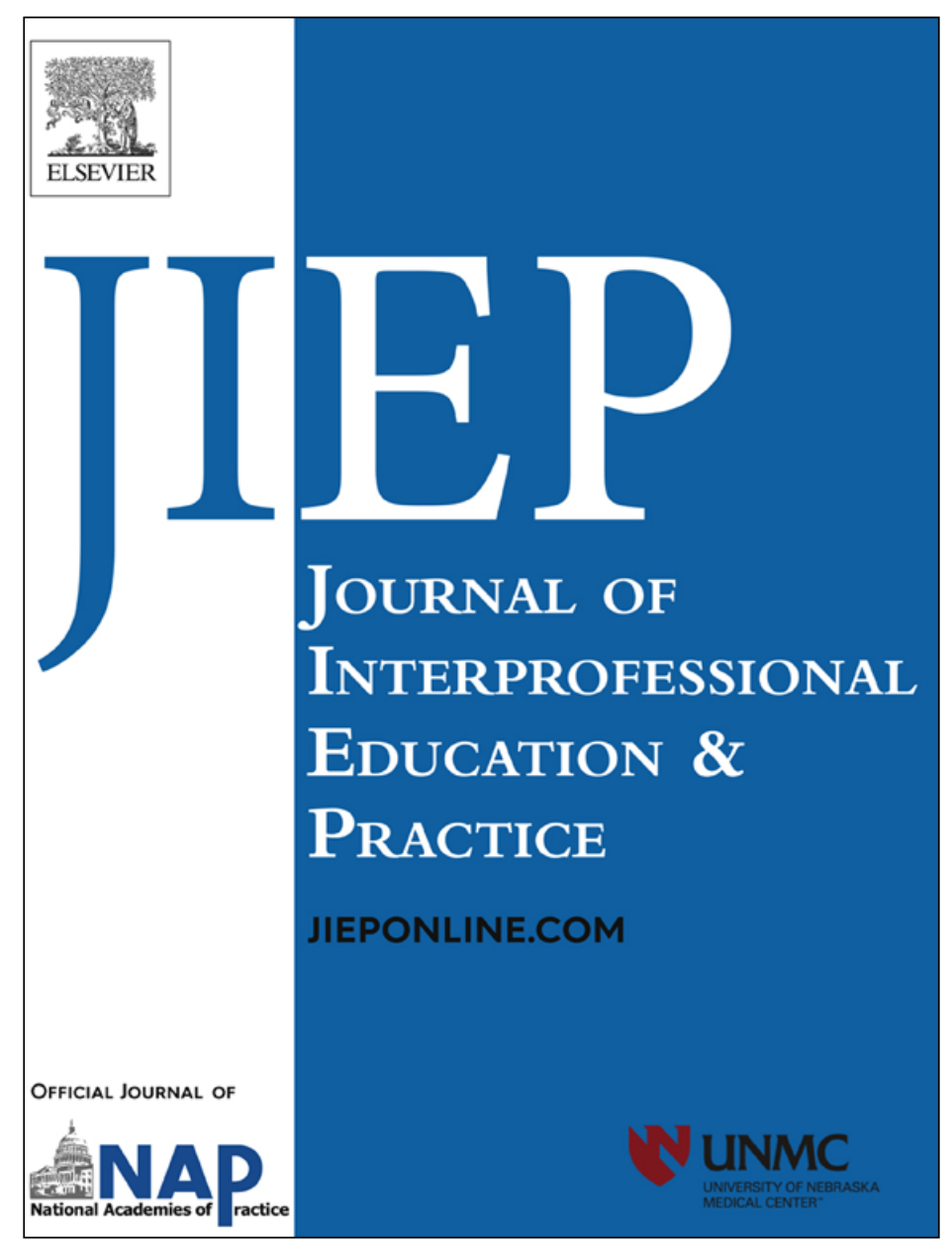

(This is a sample cover image for this issue. The actual cover is not yet available at this time.)

This article appeared in a journal published by Elsevier. The attached copy is furnished to the author for internal non-commercial research and education use, including for instruction at the author's institution and sharing with colleagues.

Other uses, including reproduction and distribution, or selling or licensing copies, or posting to personal, institutional or third party websites are prohibited.

In most cases authors are permitted to post their version of the article (e.g. in Word or Tex form) to their personal website or institutional repository. Authors requiring further information regarding Elsevier's archiving and manuscript policies are encouraged to visit:

http://www.elsevier.com/authorsrights 
Short Communication

\title{
Using a culinary health curriculum to teach teamwork skills: A new interprofessional education experience for medical, nursing and physician assistant students
}

\author{
David W. Musick *, David B. Trinkle, Joalenn Tabor \\ Interprofessional Learning Domain, Virginia Tech Carilion School of Medicine, 2 Riverside Circle, Roanoke, VA, 24016, United States
}

\section{A B S T R A C T}

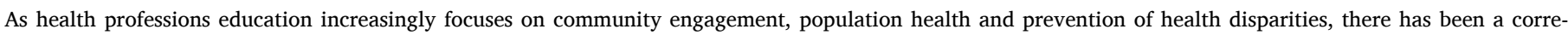

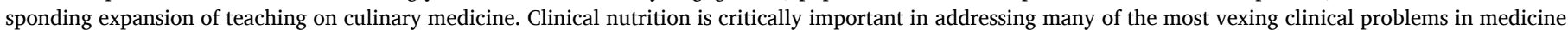

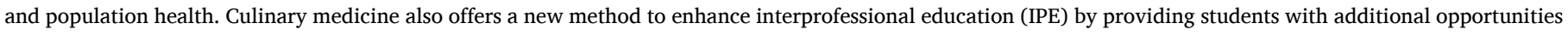
to learn with, about and from each other (as recommended by the World Health Organization).

We revised our existing IPE curriculum to deliver new content on culinary medicine as part of an existing twelve-month IPE course. Students from three different

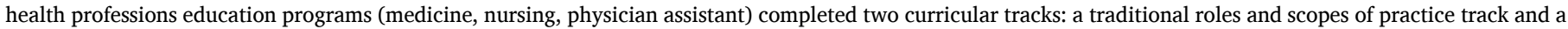

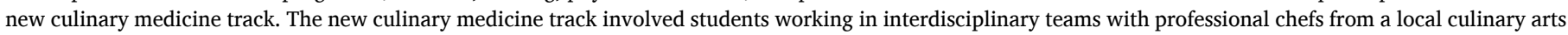

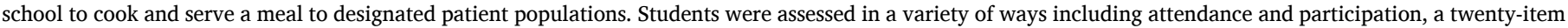

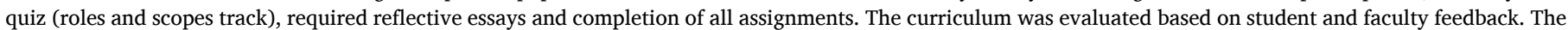

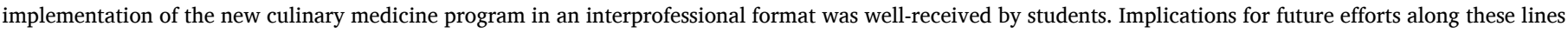

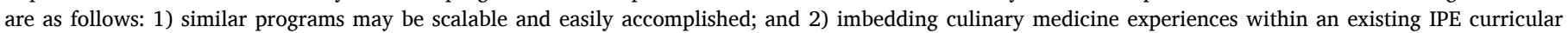

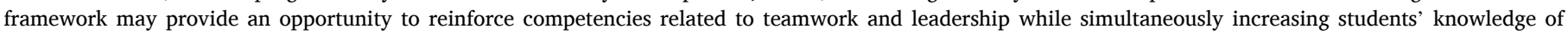
clinical nutrition.

\section{Format}

A cadre of approximately twenty faculty members used a variety of teaching methods to deliver the curriculum. These included didactic presentations, small group learning sessions, simulation-based experiences, panel presentations, two meal preparation lab sessions in a commercial kitchen, a community outreach/service learning activity, preparation of a collection of healthy recipes, and a case-based learning activity whereby student teams worked through patient scenarios featuring nutrition as a prominent clinical issue.

\section{Target audience}

Culinary medicine education is growing rapidly as more schools teach food preparation and design accompanying community service experiences. ${ }^{1-4}$ Our medical school, in collaboration with a partner institution (Radford University), has a ten-year tradition of offering IPE whereby students from three disciplines learn together during a variety of activities. ${ }^{5,6}$ The IPE curriculum is delivered to pre-clinical students from medicine, nursing and physician assistant programs $(\mathrm{N}=$ 130-140). In considering novel ways to refine the IPE curriculum, it became apparent that team activity in a large commercial training kitchen could potentially address both clinical nutrition and interprofessional teamwork. A commercial kitchen offers many analogies to fast paced hospital care teams. For example, team members working in a commercial kitchen must:

- Operate in a fast-paced and hectic environment that requires a team approach;

- Possess unique skill sets and a common understanding of and appreciation for the contributions of each team member;

- Exercise a high degree of effective communication;

- Emphasize safety and quality, and have a plan in place for reacting to any mishaps or errors in the meal preparation and service process;

- Create and deliver a service and products that are focused on consumer needs and desires, with attention paid to consumer feedback and quality ratings;

\footnotetext{
* Corresponding author.

E-mail address: dwmusick@vt.edu (D.W. Musick).
} 
- Engage in population health, in that they frequently create meals for consumers based on the needs of certain populations and educate those consumers about steps they can take to improve their quality of life.

While clinicians often encourage their patients to "eat and cook healthy," they may do so with little practical knowledge about how to educate their patients in this regard. Health professions students should learn about clinical nutrition and the dietary needs of special populations early in their course of study, so that upon entering the clinical portion of their training and eventual practice they are equipped to engage with patients around these topics.

\section{Objectives}

The goals of the new culinary medicine track were three-fold: 1) to deliver the IPEC core competencies in an applied manner via culinary training; 2) to deliver basic concepts of nutrition to our pre-clinical students; and, 3) to equip our learners to apply culinary medicine skills in addressing the difficulties inherent in telling patients to "eat and cook healthy". Specific objectives for each teaching session within both tracks were developed, and will be shared with interested persons upon request.

\section{Activity description}

Our new interprofessional culinary medicine curriculum was launched in July of 2017. Due to the size of the overall cohort (164 students from three disciplines), approximately half of the students experienced each curricular track during both fall and spring semesters. An interdisciplinary team of course directors (physician, nursing, physician assistant and health psychology faculty) designed the new two-track system. We divided students into fourteen small groups of approximately nine students per group. Approximately $3 \mathrm{~h}$ per week of formal curricular time were allocated to IPE. Seven faculty members from a variety of disciplines delivered the small group content, with each faculty member responsible for two student groups that met backto-back on Monday afternoons. These seven faculty members were designated as "TAG" (team action group) preceptors. Other portions of the curriculum were delivered by occasional guest speakers or panel members. Fig. 1 presents an overview of the topics and objectives for both curricular tracks.

We implemented the two-track system by delivering content simultaneously in both tracks over an eight-week period. Most elements of the traditional roles and scopes curricular track have been described elsewhere, ${ }^{5,6}$ and involved students learning about programs of study, scopes of practice, team leadership in healthcare, professional role controversies and patient voice/experiences. The new culinary medicine track featured three components: 1) delivery of core content pertaining to clinical nutrition; 2 ) team-based meal preparation and service; and 3) community outreach. For component one, students completed a nutrition "self-analysis" exercise wherein they logged their own food consumption over a three day period via the MyPlate online app ${ }^{7}$ (which had to include a weekend day) and participated in an interactive didactic session on clinical nutrition. During the first year of the new track, students worked in teams to produce a book of healthy recipes; during the second year, the previous recipe book was eliminated and students were required to work within their TAGs on assigned cases featuring clinical nutrition issues related to patient management. For component two, interdisciplinary student teams worked together during two lab sessions in a local culinary school with commercial kitchens wherein they cooked and served five different types of meals to volunteer audiences; meals were based on the dietary needs of identified patient populations (e.g., heart healthy, diabetic). Three experienced chefs from a local culinary school designed the population-based menus and guided students through the meal preparation and service processes. The chefs helped students understand the difficulty that some patients may have adhering to dietary restrictions due to the lack of taste and texture in many dishes that are part of a restricted diet, and taught students how to use ingredients and spices to improve the taste and texture of food. Students served the meals to a variety of groups on seven different occasions, and leftover food was packaged and donated to the local Ronald McDonald house charity. For component three, students worked together on a nutrition-oriented community outreach project. Students were provided with age-appropriate materials and training/guidance through our local university's cooperative extension program. During the first year of the new culinary track, students taught nutrition concepts to children in various age groups at 7-8 different locations across the city. Based on logistical challenges, we revised this experience during the second year so that students worked with a single community organization to deliver an outreach program to elementary and middle school aged children enrolled in an after-school program in an economically depressed area of the city. This program (entitled "Bodies and Bites") involved our students giving a brief presentation on healthy eating habits and assisting youth in preparing healthy snacks based on specific parts of the human body. For example, students worked with youth to construct a model of a beating heart, and then assisted the youth in preparing a heart-healthy snack.

At the end of the entire year, all students from both tracks came together to participate in a final wrap-up event, the health care team challenge. This experience was based on the literature, ${ }^{8}$ and featured a complex patient case wherein students worked in newly assigned interdisciplinary teams to design a patient management plan based on limited resources. Students presented their patient management plans to their peers and course faculty.

\section{Assessment}

TAG preceptors assessed each student's attendance, preparation and level of participation in all required activities, with students earning 0 points (absent or disruptive group behavior), 1 point (no, minimal or inappropriate participation) or 2 points (effective participation). Within the roles and scopes track, students completed a twenty-item quiz, which allowed up to three attempts to pass; all students passed the quiz successfully. For most small group sessions, students were assigned key readings; for all such sessions they were assessed on assignment completion as well as preparation for and participation in small group discussions. Within the culinary medicine track, students also submitted reflective essays (between 400 and 500 words) that were graded by TAG preceptors with students earning from 0 to 3 points for their essays. All final grades (pass/fail) were based on established grading criteria agreed upon by course directors from the three disciplines represented in the course.

\section{Evaluation}

To obtain student feedback on these newly-revised experiences, we surveyed students at the end of each curricular track. Our overall system of gathering student feedback consists of administering ratings items organized into two sets: one set of "core" items that are used across all curricular experiences within the first two years of the curriculum; and a variable set of "custom" items that are designed to solicit feedback on specifics of instruction within each curricular experience. Students from all three disciplines rated each course evaluation item using a 5-point Likert scale $(1=$ strongly disagree to $5=$ strongly agree). We also asked students to rate the teaching effectiveness of their TAG preceptors at the end of each curricular track. Students rated each TAG preceptor item using a similar 5-point Likert scale $(1=$ very ineffective to $5=$ very effective).

A total of 252 standardized student ratings forms were received across two academic years (142 of 168 [84.5\%] from 84 medical students; 53 of 160 [33\%] from 80 nursing students; 57 of 168 [34\%] from 


\begin{tabular}{|c|c|c|c|c|}
\hline & $\begin{array}{c}\text { Roles and Scopes Track } \\
\text { Session Topic }\end{array}$ & $\begin{array}{l}\text { Roles and Scopes Track } \\
\text { Session Objectives }\end{array}$ & $\begin{array}{l}\text { Culinary Track } \\
\text { Session Topic }\end{array}$ & $\begin{array}{c}\text { Culinary Track } \\
\text { Session Objectives }\end{array}$ \\
\hline One & $\begin{array}{l}\text { Introduction to Roles and } \\
\text { Scopes } \\
\text { Guest Interdisciplinary } \\
\text { Clinician Panel }\end{array}$ & $\begin{array}{l}\text { Appraise the } \\
\text { significance of } \\
\text { teamwork in healthcare } \\
\text { quality improvement, } \\
\text { patient safety, patient } \\
\text { perspective, and } \\
\text { achievement of positive } \\
\text { patient outcomes. } \\
\text { Be able to communicate } \\
\text { ones roles and } \\
\text { responsibilities clearly } \\
\text { to other healthcare } \\
\text { professionals and how } \\
\text { the team works together. }\end{array}$ & $\begin{array}{l}\text { Introduction to } \\
\text { Culinary Medicine }\end{array}$ & $\begin{array}{l}\text { Demonstrate an } \\
\text { awareness of one's own } \\
\text { role and scope of } \\
\text { practice in a commercial } \\
\text { kitchen, as well as that } \\
\text { of others, in preparing a } \\
\text { meal that will address } \\
\text { dietary needs of special } \\
\text { patient populations. } \\
\text { Listen actively and } \\
\text { encourage the ideas and } \\
\text { opinions of other team } \\
\text { members. }\end{array}$ \\
\hline Two & $\begin{array}{l}\text { Communication \& } \\
\text { SBAR/CUS }\end{array}$ & $\begin{array}{l}\text { Demonstrate effective } \\
\text { communication skills } \\
\text { with team members } \\
\text { utilizing SBAR } \\
\text { techniques and tools. } \\
\text { Provide appropriate } \\
\text { feedback to team } \\
\text { members utilizing } \\
\text { TeamSTEPPS framework } \\
\text { of knowledge, attitudes } \\
\text { and performance to } \\
\text { achieve effective } \\
\text { communication. }\end{array}$ & $\begin{array}{l}\text { Overview of Clinical } \\
\text { Nutrition and } \\
\text { Population Health }\end{array}$ & $\begin{array}{l}\text { Develop a working } \\
\text { knowledge of healthier } \\
\text { foods and how they } \\
\text { relate to a variety of } \\
\text { patient dietary needs. } \\
\text { Complete the assigned } \\
\text { self-nutrition } \\
\text { assessment exercise. } \\
\text { Work with your } \\
\text { interdisciplinary team to } \\
\text { complete the clinician } \\
\text { nutrition patient case } \\
\text { assignment. }\end{array}$ \\
\hline Three & $\begin{array}{c}\text { Programs of Study - } \\
\text { Academic Differences \& } \\
\text { Similarities }\end{array}$ & $\begin{array}{l}\text { Articulate the } \\
\text { requirements for and } \\
\text { educational training of } \\
\text { medical students, } \\
\text { physician assistant } \\
\text { students and } \\
\text { accelerated bachelors } \\
\text { nursing students. }\end{array}$ & $\begin{array}{c}\text { Culinary Lab } 1 \text { (Intro } \\
\text { to Commercial } \\
\text { Kitchen, Meal } \\
\text { Planning) }\end{array}$ & $\begin{array}{l}\text { Develop a working } \\
\text { knowledge of health } \\
\text { cooking techniques, } \\
\text { including appreciation } \\
\text { for teamwork } \\
\text { techniques in the } \\
\text { kitchen that serve as an } \\
\text { analogy for teamwork } \\
\text { skills in healthcare. }\end{array}$ \\
\hline Four & $\begin{array}{l}\text { Roles, Scopes, \& Patient } \\
\text { Voice } \\
\text { Family Advisory Council }\end{array}$ & $\begin{array}{l}\text { Acknowledge the } \\
\text { unique role of } \\
\text { healthcare team } \\
\text { members to listen and }\end{array}$ & $\begin{array}{l}\text { Lab } 2 \text { (Meal } \\
\text { Preparation, } \\
\text { Presentation) }\end{array}$ & $\begin{array}{l}\text { Develop a working } \\
\text { knowledge of health } \\
\text { cooking techniques, } \\
\text { including appreciation } \\
\text { for teamwork }\end{array}$ \\
\hline
\end{tabular}

Fig. 1. Session Titles and Objectives, Roles and Scopes and Culinary Medicine Tracks.

84 physician assistant students). Student ratings results (combined across all three student groups) for each track are displayed in Table 1. There were no statistically significant differences between item means for the core items when comparing the culinary and roles/scopes curricular tracks. Student ratings results for TAG preceptors across both academic years were very strong, with all seven preceptors rated highly (from 4.1 to 5.0 on a Likert type scale, wherein $1=$ very ineffective to 5
$=$ very effective). A comparison of student ratings between the two academic years is displayed in Tables 2 and 3. In comparing ratings for both tracks between the first and second years of implementation, we noted a trend for slightly higher student ratings of both tracks during the second year of the revised curriculum. We also noted a trend whereby students who experienced the roles and scopes track first tended to rate the culinary track slightly higher, in comparison to students who 


\begin{tabular}{|c|c|c|c|c|}
\hline & & $\begin{array}{l}\text { honor patients and } \\
\text { family perspectives and } \\
\text { choices. }\end{array}$ & & $\begin{array}{l}\text { techniques in the } \\
\text { kitchen that serve as an } \\
\text { analogy for teamwork } \\
\text { skills in healthcare. }\end{array}$ \\
\hline Five & $\begin{array}{c}\text { Healthcare Roles and } \\
\text { Responsibilities \& } \\
\text { Professional } \\
\text { Controversies/Challenges }\end{array}$ & $\begin{array}{l}\text { Develop awareness and } \\
\text { appreciation of one's } \\
\text { own role, scope of } \\
\text { practice and roles of } \\
\text { other professions to } \\
\text { appropriately assess } \\
\text { and address the needs } \\
\text { of patients and } \\
\text { caregivers. }\end{array}$ & $\begin{array}{c}\text { Feeding America } \\
\text { Session }\end{array}$ & $\begin{array}{l}\text { Work as a productive } \\
\text { member of a team to } \\
\text { deliver educational } \\
\text { content pertaining to } \\
\text { nutrition to school-aged } \\
\text { children. }\end{array}$ \\
\hline Six & $\begin{array}{c}\text { Simulated Team Meeting } \\
\text { (OSCE) } \\
\text { Teams 1-3 }\end{array}$ & $\begin{array}{l}\text { Develop further } \\
\text { awareness and } \\
\text { appreciation of the } \\
\text { roles and contributions } \\
\text { of various healthcare } \\
\text { professionals in } \\
\text { providing quality, safe } \\
\text { patient care and how } \\
\text { the team works } \\
\text { together. }\end{array}$ & $\begin{array}{c}\text { Bodies and Bites } \\
\text { Session One (Lesson } \\
\text { Planning) }\end{array}$ & $\begin{array}{l}\text { Work as a productive } \\
\text { member of a team to } \\
\text { deliver educational } \\
\text { content pertaining to } \\
\text { nutrition to school-aged } \\
\text { children, including the } \\
\text { delivery of a healthy } \\
\text { snack. }\end{array}$ \\
\hline Seven & $\begin{array}{c}\text { Simulated Team Meeting } \\
\text { (OSCE) } \\
\text { Teams 4-6 }\end{array}$ & $\begin{array}{l}\text { Develop further } \\
\text { awareness and } \\
\text { appreciation of the } \\
\text { roles and contributions } \\
\text { of various healthcare } \\
\text { professionals in } \\
\text { providing quality, safe } \\
\text { patient care and how } \\
\text { the team works } \\
\text { together. }\end{array}$ & $\begin{array}{c}\text { Bodies and Bites } \\
\text { Session Two (West } \\
\text { End Center) }\end{array}$ & $\begin{array}{l}\text { Work as a productive } \\
\text { member of a team to } \\
\text { deliver educational } \\
\text { content pertaining to } \\
\text { nutrition to school-aged } \\
\text { children, including the } \\
\text { delivery of a health } \\
\text { snack. }\end{array}$ \\
\hline Eight & $\begin{array}{c}\text { Debrief - Roles and } \\
\text { Scopes Track }\end{array}$ & $\begin{array}{l}\text { Demonstrate } \\
\text { proficiency in utilizing } \\
\text { team debrief and } \\
\text { communication models } \\
\text { presented in the course. }\end{array}$ & $\begin{array}{c}\text { Debrief - Culinary } \\
\text { Track }\end{array}$ & $\begin{array}{l}\text { Demonstrate } \\
\text { proficiency in utilizing } \\
\text { team debrief and } \\
\text { communication models } \\
\text { presented in the course. }\end{array}$ \\
\hline Nine & $\begin{array}{l}\text { Health Care Team } \\
\text { Challenge (HCTC) }\end{array}$ & $\begin{array}{l}\text { Demonstrate } \\
\text { proficiency in using } \\
\text { one's understanding of } \\
\text { various health } \\
\text { professions roles and } \\
\text { scopes of practice to } \\
\text { form an ideal healthcare } \\
\text { team and create a care } \\
\text { plan for a complicated } \\
\text { patient case. }\end{array}$ & $\begin{array}{l}\text { Health Care Team } \\
\text { Challenge (НСТC) }\end{array}$ & $\begin{array}{l}\text { Demonstrate } \\
\text { proficiency in using } \\
\text { one's understanding of } \\
\text { various health } \\
\text { professions roles and } \\
\text { scopes of practice to } \\
\text { form an ideal healthcare } \\
\text { team and create a care } \\
\text { plan for a complicated } \\
\text { patient case. }\end{array}$ \\
\hline
\end{tabular}

Fig. 1. (continued).

experienced the culinary track prior to the roles and scopes track (data not shown).

We consistently received comments from approximately $15 \%-20 \%$ of students enrolled in the course, and we looked carefully at the comments to ascertain specific recommendations for strengthening the overall curriculum and, in particular, the new culinary medicine track.
The most prominent themes from these comments are summarized below:

- The course was enjoyable overall, but for some students the culinary medicine track did not make a strong "connection" between the 
Table 1

Student Ratings of Core and Custom Items, Culinary and Roles \& Scopes Track (Combined Ratings Across Two Academic Years).

\begin{tabular}{|c|c|c|c|c|c|}
\hline & $\begin{array}{l}\text { Ratings } \\
\text { Type }\end{array}$ & $\begin{array}{l}\text { Number of } \\
\text { Ratings }\end{array}$ & Culinary Track & Roles/Scopes Track & $\begin{array}{l}\mathrm{P} \\
\text { value }\end{array}$ \\
\hline Ratings Item & & & $\begin{array}{l}\text { Mean Rating } \\
\text { (Standard } \\
\text { Deviation) }\end{array}$ & $\begin{array}{l}\text { Mean Rating } \\
\text { (Standard } \\
\text { Deviation) }\end{array}$ & \\
\hline I had adequate opportunity to seek help from Interprofessionalism faculty & Core & $\begin{array}{l}\mathrm{Cul}=125 \\
\mathrm{RS}=138\end{array}$ & $4.05(.76)$ & $4.12(.77)$ & 0.27 \\
\hline I achieved the Block II Interprofessionalism (culinary track) learning objectives & Core & $\begin{array}{l}\mathrm{Cul}=142 \\
\mathrm{RS}=143\end{array}$ & $3.80(.91)$ & $3.98(.75)$ & 0.48 \\
\hline My culinary track experience was positive overall & Core & $\begin{array}{l}\mathrm{Cul}=142 \\
\mathrm{RS}=142\end{array}$ & $3.80(.93)$ & $3.93(.82)$ & 0.48 \\
\hline The culinary track content was delivered effectively & Core & $\begin{array}{l}\mathrm{Cul}=138 \\
\mathrm{RS}=143\end{array}$ & $3.53(.95)$ & $3.65(.89)$ & 0.38 \\
\hline The culinary track organization and directions were effective for navigating the course & Core & $\begin{array}{l}\mathrm{Cul}=142 \\
\mathrm{RS}=143\end{array}$ & $3.50(.99)$ & $3.90(.81)$ & 0.48 \\
\hline Average: Core Items & & & $3.74(.91)$ & $3.92(.81)$ & \\
\hline $\begin{array}{l}\text { The Bodies and Bites experience allowed me to practice teaching nutrition concepts to } \\
\text { different populations }\end{array}$ & Custom & 77 & $3.80(1.06)$ & & \\
\hline $\begin{array}{l}\text { The content/activities during the nutrition lecture allowed me to better understand the } \\
\text { difficulties in patient monitoring status and provided me with a basic understanding of } \\
\text { nutrition }\end{array}$ & Custom & 142 & 3.78 (.99) & & \\
\hline $\begin{array}{l}\text { My experience working with a team in a kitchen provided a practical opportunity to } \\
\text { experience roles/scopes in a busy team environment }\end{array}$ & Custom & 134 & $3.73(1.09)$ & & \\
\hline $\begin{array}{l}\text { The Intro session on culinary health allowed me to be better prepared to work with a team } \\
\text { in a community kitchen and prepare a meal for special populations }\end{array}$ & Custom & 134 & $3.47(.99)$ & & \\
\hline $\begin{array}{l}\text { The Health Care Team Challenge was a good culminating event to reinforce } \\
\text { interprofessional core competencies and learning }\end{array}$ & Custom & 72 & $3.35(1.12)$ & & \\
\hline $\begin{array}{l}\text { The Feeding America experience allowed me to practice teaching nutrition concepts to } \\
\text { different populations }\end{array}$ & Custom & 62 & $3.30(1.10)$ & & \\
\hline $\begin{array}{l}\text { The Academic Differences and Similarities session helped me better understand the } \\
\text { preparation that other healthcare disciplines go through }\end{array}$ & Custom & 142 & & $4.15(.78)$ & \\
\hline $\begin{array}{l}\text { The Family Advisory Council was effective at bringing patient and family voice into the } \\
\text { healthcare team setting }\end{array}$ & Custom & 141 & & $4.03(.87)$ & \\
\hline $\begin{array}{l}\text { The OSCE experience (Ivan P. Evans) increased my awareness of the roles, scope of } \\
\text { practice, and contributions of the other healthcare professions }\end{array}$ & Custom & 142 & & $4.00(.93)$ & \\
\hline $\begin{array}{l}\text { Through various activities this block (Healthcare Controversies/Challenges, Introductory } \\
\text { Panel Discussion, etc.) I feel that I am able to better value the roles, scopes of practice, } \\
\text { and contributions of other healthcare professions as a member of an interprofessional } \\
\text { team }\end{array}$ & Custom & 141 & & $3.80(.85)$ & \\
\hline $\begin{array}{l}\text { The patient safety and teamwork exercises (CUS and SBAR) were effective in helping me } \\
\text { better understand different communication methods }\end{array}$ & Custom & 143 & & $3.68(1.00)$ & \\
\hline $\begin{array}{l}\text { The Health Care Team Challenge was a good culminating event to reinforce } \\
\text { interprofessional core competencies and learning }\end{array}$ & Custom & 51 & & $3.55(.90)$ & \\
\hline Average: Custom Items & & & $3.57(1.06)$ & $3.87(.89)$ & \\
\hline
\end{tabular}

analogy of a commercial kitchen being similar to a busy patient care environment;

- The clinically-focused activities (e.g., working through paper cases featuring nutrition issues, the simulation/OSCE experience) were well-received, and students desired more of these types of experiences wherein they could practice skills they had learned;

- Certain aspects of course delivery (e.g., service learning component in the first year of the course) needed to be better organized;

- Small group activities where students learned about the roles and training of other healthcare providers was well-received;

- The healthcare team challenge could have been shortened and made more effective by a tighter focus on the clinical issues related to the case;

- Some physician assistant students felt that the course gave inadequate attention to the role of the PA.

\section{Impact}

As part of a revised IPE curriculum, we implemented a new culinary medicine education track over two consecutive academic years and reviewed student feedback for course improvement. While generally received positively by students, this new curricular track was very laborintensive and not particularly impactful in terms of orienting students to the demands of clinical patient care teams. While end-of-course feedback scores improved during year two, students still had varied perceptions of the new culinary medicine curriculum in terms of its effectiveness in helping them learning core IPE objectives. The observed trend whereby the culinary medicine portion of curriculum was rated more favorably during the second academic year was likely due to logistical changes made after the first year in response to student feedback. In particular, we changed the nutrition-related service-learning portion of the curriculum to a single experience with one community agency, resulting in a more cohesive, organized experience for the students.

We also noted that the project achieved mixed results concerning the objectives pertaining to nutrition education and population health. Students rated their experiences in learning about nutrition favorably (3.78 on a five point Likert scale) and many students expressed appreciation for this content anecdotally. However, the students rated the population health aspect of the curriculum lower (3.47 on a five point Likert scale). Although our curriculum introduced them to the students, it is likely that the topics of nutrition and population health are too broad to cover effectively in a single culinary medicine experience.

The observed trend whereby students who rated the culinary track higher after having first experienced the roles and scopes of practice track was unexpected. We speculate that this trend may be due to the fact that students who experienced the roles and scopes track first had the opportunity to get to know each other better, and therefore may have brought more of a sense of team cohesion into the culinary experiences after having already spent significant time in small groups. 
Table 2

Student Ratings of Core and Custom Items by Academic Year (Culinary Track)a

\begin{tabular}{|c|c|c|c|c|}
\hline Item & Type & $\begin{array}{l}\text { 2017-2018 Mean Rating } \\
\text { (Standard Deviation) }\end{array}$ & $\begin{array}{l}\text { 2018-2019 Mean Rating } \\
\text { (Standard Deviation) }\end{array}$ & $\begin{array}{l}\mathrm{P} \\
\text { value }+\end{array}$ \\
\hline I had adequate opportunity to seek help from Interprofessionalism faculty & Core & $3.95(.82)$ & $4.15(.70)$ & 0.43 \\
\hline I achieved the Block II Interprofessionalism (culinary track) learning objectives & Core & $3.65(.97)$ & $3.95(.83)$ & 0.26 \\
\hline My culinary track experience was positive overall & Core & $3.60(.97)$ & $4.00(.88)$ & 0.22 \\
\hline The culinary track content was delivered effectively & Core & $3.15(1.03)$ & $3.90(.86)$ & 0.37 \\
\hline The culinary track organization and directions were effective for navigating the course & Core & $3.00(1.15)$ & $4.00(.83)$ & 0.29 \\
\hline Average: Core Items & & $3.47(.99)$ & $4.00(.82)$ & \\
\hline $\begin{array}{l}\text { The Feeding America/Bodies and Bites experience allowed me to practice teaching nutrition } \\
\text { concepts to different populations }\end{array}$ & Custom & $3.30(1.05)$ & $3.70(1.10)$ & 0.27 \\
\hline $\begin{array}{l}\text { The content/activities during the nutrition lecture allowed me to better understand the } \\
\text { difficulties in patient monitoring status and provided me with a basic understanding of } \\
\text { nutrition }\end{array}$ & Custom & $3.65(1.09)$ & $3.90(1.10)$ & 0.20 \\
\hline $\begin{array}{l}\text { My experience working with a team in a kitchen provided a practical opportunity to experience } \\
\text { roles/scopes in a busy team environment }\end{array}$ & Custom & $3.55(1.13)$ & $3.90(1.04)$ & 0.28 \\
\hline $\begin{array}{l}\text { The Intro session on culinary health allowed me to be better prepared to work with a team in a } \\
\text { community kitchen and prepare a meal for special populations }\end{array}$ & Custom & Not rated & $3.50(.95)$ & $\mathrm{n} / \mathrm{a}$ \\
\hline $\begin{array}{l}\text { The Health Care Team Challenge was a good culminating event to reinforce interprofessional } \\
\text { core competencies and learning }\end{array}$ & Custom & $3.00(1.24)$ & $3.70(.43)$ & 0.43 \\
\hline Average: Custom Items & & $3.38(1.13)$ & $3.74(.99)$ & \\
\hline
\end{tabular}

${ }^{\text {a }}$ Rating scale: $5=$ strongly agree; $4=$ agree; $3=$ neither agree/disagree; $2=$ disagree; $1=$ strongly disagree.

Strengths of our curriculum included a large student base from three disciplines and the mandatory requirements for medical, nursing and physician assistant students to participate. Limitations included the fact that our curriculum is in place at a single institution, and the reliance on only two years of student feedback data.

We conclude that the implementation of a culinary medicine program involving students from three disciplines achieved mixed results. Imbedding culinary medicine experiences within an existing IPE curricular framework may provide a viable opportunity to further reinforce team learning and leadership while simultaneously increasing students' knowledge of clinical nutrition. However, providing a culinary medicine program in an interprofessional manner requires a "heavy lift" from a logistical standpoint. Determining the precise manner in which this material can be provided to various groups of health professions students, so that the students gain insights into how team competencies apply to clinical care, is challenging.

\section{Required materials}

The delivery of a culinary medicine curriculum requires a detailed curricular plan and abundant logistical support. Resources required for our IPE program include detailed educational objectives for each session within each of the two curricular tracks. A culinary medicine program requires specialized faculty as well as access to a kitchen area that can accommodate students and instructors, and access to a dining area where prepared meals can be served. All course faculty and students also had access to an online course management system whereby course materials, assignments, grades and announcements were posted for review. All course materials are available by contacting the lead author at dwmusick@vt.edu.

Rating scale: $5=$ strongly agree; $4=$ agree; $3=$ neither agree/ disagree; 2 = disagree; 1 = strongly disagree.

$+\mathrm{T}$-test, statistical significance level $\mathrm{p}=0.05$.

+ T-test, statistical significance level $\mathrm{p}=0.05$.

Table 3

Student Ratings of Core and Custom Items by Academic Year (Roles \& Scopes Track) ${ }^{\mathrm{a}}$

\begin{tabular}{|c|c|c|c|c|}
\hline Item & Type & $\begin{array}{l}\text { 2017-2018 Mean Rating } \\
\text { (Standard Deviation) }\end{array}$ & $\begin{array}{l}\text { 2018-2019 Mean Rating } \\
\text { (Standard Deviation) }\end{array}$ & $\begin{array}{l}\mathrm{P} \\
\text { value+ }+\end{array}$ \\
\hline I had adequate opportunity to seek help from Interprofessionalism faculty & Core & $4.15(.71)$ & $4.10(.83)$ & 0.11 \\
\hline I achieved the Block III/IV Interprofessionalism (Roles and Scopes Track) learning objectives & Core & $4.10(.75)$ & $3.85(.75)$ & 0.21 \\
\hline My roles and scopes track experience was positive overall & Core & $4.00(.82)$ & $3.85(.50)$ & 0.23 \\
\hline The roles and scopes track was well-organized & Core & $3.75(.88)$ & $4.05(.74)$ & 0.14 \\
\hline The roles and scopes track content was delivered effectively & Core & $3.60(.96)$ & $3.70(.80)$ & 0.24 \\
\hline Average: Core Items & & $3.92(.82)$ & $3.91(.72)$ & \\
\hline $\begin{array}{l}\text { The Academic Differences and Similarities session helped me better understand the preparation } \\
\text { that other healthcare disciplines go through }\end{array}$ & Custom & $4.20(.74)$ & $4.10(.82)$ & 0.14 \\
\hline $\begin{array}{l}\text { The Family Advisory Council was effective at bringing patient and family voice into the } \\
\text { healthcare team setting }\end{array}$ & Custom & $4.00(.86)$ & $4.05(.87)$ & 0.11 \\
\hline $\begin{array}{l}\text { The OSCE experience (Ivan P. Evans) increased my awareness of the roles, scope of practice, } \\
\text { and contributions of the other healthcare professions }\end{array}$ & Custom & $4.10(.84)$ & $3.90(1.01)$ & 0.06 \\
\hline $\begin{array}{l}\text { Through various activities this block (Healthcare Controversies/Challenges, Introductory } \\
\text { Panel Discussion, etc.) I feel that I am able to better value the roles, scopes of practice, and } \\
\text { contributions of other healthcare professions as a member of an interprofessional team }\end{array}$ & Custom & $3.85(.80)$ & $3.75(.88)$ & 0.22 \\
\hline $\begin{array}{l}\text { The patient safety and teamwork exercises (CUS and SBAR) were effective in helping me better } \\
\text { understand different communication methods }\end{array}$ & Custom & $3.70(1.10)$ & $3.65(.89)$ & 0.16 \\
\hline $\begin{array}{l}\text { The Health Care Team Challenge was a good culminating event to reinforce interprofessional } \\
\text { core competencies and learning }\end{array}$ & Custom & $3.30(1.20)$ & $3.80(.60)$ & 0.28 \\
\hline Average: Custom Items & & $3.86(.92)$ & $3.88(.84)$ & \\
\hline
\end{tabular}

${ }^{\text {a }}$ Rating scale: $5=$ strongly agree; $4=$ agree; $3=$ neither agree/disagree; $2=$ disagree; $1=$ strongly disagree. 


\section{CRediT authorship contribution statement}

David W. Musick: Conceptualization, Writing - original draft, Formal analysis. David B. Trinkle: Conceptualization, Writing - review \& editing. Joalenn Tabor: Project administration, Writing - review \& editing.

\section{References}

1. Polak R, Phillips EM, Nordgren J, et al. Health-related culinary education: a summary of representative emerging programs for health professionals and patients. Glob Adv Health Med. 2016;5(1):61-68.

2. Leong B, Ren D, Monlezun D, et al. Teaching third and fourth year medical students how to cook: an innovative approach to training students in lifestyle modification for chronic disease management. Med Sci Educ. 2014;24(1):43.
3. Birkhead AG, Foote S, Monlezun D, et al. Medical student-led community cooking classes: a novel preventive medicine model that's easy to swallow. Am J Prev Med. 2014;46(3):e41-42.

4. Razavi AC, Monlezun DJ, Sapin A. Multisite culinary medicine curriculum is associated with cardioprotective dietary patterns and lifestyle medicine competencies among medical trainees. Am J Lifestyle Med. 2020;14(2):225-233.

5. Vari PM, Lash J, Brown SS, et al. Collaborative practice education: the effect of an interprofessional teamwork course on students' knowledge and skills. Med Sci Educ. 2013:23(3S):494-501.

6. Trinkle DB, Schnurman-Crook A, Porter AG, et al. Stumbling and succeeding together: a new medical school's collaborative initiative to elevate interprofessionalism as a signature hallmark in training future healthcare leaders. Med Sci Educ. 2014;24(2): 219-223.

7. United States Department of Agriculture. Choose MyPlate. Available online at: http s://www.choosemyplate.gov/. Accessed February 27, 2020.

8. Richardson B, Gersh M, Potter N. Health care team challenge: a versatile model for interprofessional education. MedEdPORTAL. 2012;8:9287. https://doi.org/10.15766/ mep_2374-8265.9287. . Accessed February 27, 2020. 